logos_i_ethos_2019_2_(50), s. 87-106

DOI: http://dx.doi.org/10.15633/lie.3479

Agnieszka Janas

https://orcid.org/0000-0002-1153-6463

Uniwersytet Papieski Jana Pawła II w Krakowie

\title{
Analiza etyczna fenomenu uczciwości na podstawie powieści Fiodora Dostojewskiego Bracia Karamazow
}

Literatura stwarza możliwości poznania świata, a jej związki z filozofią i etyką są oczywiste, ale zarazem problematyczne. Zarówno filozofia, jak i literatura zajmują się tymi samymi problemami, czyli człowiekiem oraz tym, co dla człowieka najistotniejsze - poszukiwaniem sensu i celu życia. Obie te dziedziny

Agnieszka Janas - doktor filozofii, absolwentka filologii polskiej i oligofrenopedagogiki na Uniwersytecie Pedagogicznym im. Komisji Edukacji Narodowej w Krakowie. Zainteresowania naukowe: filozofia społeczna, etyka, filozofia języka i filozofia kultury. Ważniejsze publikacje: Szczęście społeczeństwa nowego kapitalizmu wedlug Richarda Sennetta, „Logos i Ethos” 2016 (40) numer specjalny, s. 163-175. uczą prawd moralnych, są źródłem poznania tych prawd i umożliwiają człowiekowi zrozumienie samego siebie. Anna Głąb uważa, że literatura piękna jest istotnym narzędziem odkrywania i pomnażania poznania ${ }^{1}$. Sama struktura dzieła, której fundamentem jest narracja, stanowi dla odbiorcy zachętę do interpretacji przy użyciu kategorii etycznych, zaś niewątpliwą zaletą literatury jest możliwość praktycznego uczenia się, poprzez jej lekturę, pożądanych zachowań etycznych. To jednocześnie można uważać za estetyczną zaletę dzieła ${ }^{2}$. Dzieła literackie pomagają człowiekowi zrozumieć siebie i otaczający go świat. Dzieła literatury wypowiadają głośno problemy, zaś bohaterowie i zdarzenia stawiają mniej lub bardziej jasno pytania natury moralnej, które zmuszają czytelnika,

1 Por. A. Głąb, Literatura a poznanie moralne, Lublin 2016, s. 7.

2 Por. A. Głąb, Literatura..., dz. cyt., s. 22. 
aby zastosował posiadane pojęcia i zasady do sytuacji przedstawionej w dziele. Dostarczają one pewnych obrazów życia, które człowiek poszukujący odpowiedzi na pytanie, jak żyć, może wziąć pod uwagę. W rezultacie poszukiwanie odpowiedzi na to pytanie jest próbą osiągnięcia równowagi między przyjmowanymi pojęciami i zasadami moralnymi a konkretnymi percepcjami, które powstają na styku życia i literatury. Wiedza nabywana dzięki literaturze może być podobna do reguł i zasad przyjmowanych wcześniej, może ona również współistnieć z nimi ${ }^{3}$.

W artkule posłużę się metodą analizy etycznej w celu omówienia znaczenia fenomenu uczciwości dla relacji społecznych. Metoda analizy etycznej polega na dokonywaniu oceny dzieła literackiego z perspektywy aksjologiczno-etyczno-metafizycznej ${ }^{4}$. Przedmiotem analizy etycznej dzieła literackiego jest poszukiwanie i ocena norm i wartości moralnych, jakimi kierują się bohaterowie literaccy w swoich działaniach. Normą moralności działania ludzkiego jest godność osobowa człowieka ugruntowana w jego przedmiotowej strukturze (czyli naturze) ${ }^{5}$.

W metodzie analizy istotną rolę odgrywa przedmiot badań, którym w tym przypadku jest powieść Fiodora Dostojewskiego Bracia Karamazow. Celem metody analizy etycznej jest rozwiązywanie zagadnień najtrudniejszych, jakie niesie ze sobą rzeczywistość oraz próba udzielenia odpowiedzi na podstawowe problemy etyczne będące tematem konkretnego dzieła literackiego ${ }^{6}$. W celu dokonania oceny etycznej postaci i działań bohaterów powieści związanych z fenomenem uczciwości na gruncie wzajemnych relacji posłużę się Etyka nikomachejskg oraz Etykg wielka Arystotelesa. W tych dziełach filozof porusza problemy natury etycznej, a w Poetyce dokonuje oceny dzieła literackiego z perspektywy jego walorów poznawczych, estetycznych i etycznych.

W powieści Bracia Karamazow znajdują się przykłady uczciwości o znaczeniu uniwersalnym, które mogą mieć implikacje dla etyki jako

3 Por. A. Głąb, Literatura..., dz. cyt., s. 176.

4 Por. A. Głąb, Literatura..., dz. cyt., s. 353.

5 Por. Leksykon filozofii klasycznej, red. nauk. J. Herbut, Lublin 1997, s. 177-179.

${ }^{6}$ Por. J. Herbut, Elementy metodologii filozofii, Lublin 2004, s. 29-30. 
nauki normatywnej o ludzkim działaniu. W powieściach Dostojewskiego, podobnie jak w greckich tragediach, poruszane są problemy etyczne istotne dla człowieka. W artykule dokonuję porównania dzieła do tragedii greckiej, ponieważ uważam, że istotną rolę w możliwości interpretacji kategorii tragizmu odgrywa złamanie przez bohaterów podstawowych norm etycznych, takich jak uczciwość czy sprawiedliwość. Posiłkując się Poetykq Arystotelesa, w której omówione zostały cechy tragedii, ocenię, w jakim zakresie powieść Dostojewskiego można uznać za tragedię. Poruszane przez pisarza problemy wywołują u czytelnika uczucia litości i trwogi, które towarzyszyły widzom oglądającym tragedie. Przeanalizuję relacje między bohaterami powieści Fiodora Dostojewskiego Bracia Karamazow i wskażę na podobieństwo losu jednego z braci, Dymitra, do losu Edypa, tytułowego bohatera tragedii Sofoklesa. Arystoteles uważa, że bohater tragiczny posiada zalety etyczne, ale jego działania są często niezgodne $\mathrm{z}$ powszechnie uznawanymi zasadami.

Wielka literatura, podejmując problematykę filozoficzną czy etyczną, skupia się na zagadnieniach związanych z ludzką egzystencją, dokonuje tego w sposób intuicyjny i rzadko formułuje gotowe tezy. Poznając dzieła kultury, człowiek kształtuje własną świadomość. W procesie poznania siebie dużą rolę odgrywa wyobraźnia, która zbliża do siebie etykę, literaturę i sztukę oraz łączy ze sobą zróżnicowane doświadczenia. Człowiek może zrozumieć siebie tylko wtedy, gdy w sposób świadomy umieści siebie w perspektywie opowiadanej historii lub czytanego tekstu ${ }^{7}$.

\section{Fenomen uczciwości w ujęciu Arystotelesa}

Warto zastanowić się nad zdefiniowaniem pojęcia uczciwości na gruncie relacji społecznych. Uczciwość dotyczy postawy etycznej związanej z podstawową wartością, czyli z prawdą. Ludzie uczciwi

7 Por. E. Podrez, Rola wyobraźni w kształtowaniu świadomości moralnej, w: Wyobraźnia jako jaźń twórcza. Studia z etyki, literatury i sztuki, red. nauk. E. Podrez, A. Czyż, Warszawa 2002, s. 33-34. 
mówią prawdę, ale to nie jedyne wyjaśnienie uczciwości, która może być również rozumiana jako sprawiedliwość. Arystoteles pisze o człowieku prawdomównym:" jest i w słowach, i w życiu w zgodzie z prawdą, ponieważ taki jest jego charakter. Tego rodzaju człowiek zdaje się być człowiekiem prawym" ". Aby dokonać analizy fenomenu uczciwości, należy uwzględnić jeszcze inne konotacje związane z tym zagadnieniem. Uczciwość może być również rozumiana jako sprawiedliwość względem drugiego człowieka9 ${ }^{9}$ W kontekście tak rozumianej przez Stagirytę uczciwości warto przeanalizować jej fenomen w relacjach międzyludzkich.

Kiedy Arystoteles mówi o sprawiedliwości czy prawdomówności, zakłada pewną równość, równoprawność relacji. Innymi słowy, człowiek ma obowiązek postępować sprawiedliwie, ale może również oczekiwać, że wobec niego inni będą postępować podobnie. Filozof stwierdza:" Otóż skoro sprawiedliwość opiera się na słuszności i równości, i umiarze, to używamy pojęcia „słuszność” - słuszny względem kogoś, a "równość - równy względem kogoś, zaś „środek” - pośrodku [pomiędzy skrajnościami]; w rezultacie sprawiedliwość i słuszność będzie zachodziła w stosunku do określonych osób i określonych spraw"10. Tak zdefiniowaną sprawiedliwość warto przeanalizować w oparciu o powieść Dostojewskiego Bracia Karamazow, ponieważ ten sposób rozumienia sprawiedliwości jest sprzeczny z postawami reprezentowanymi przez bohaterów powieści, którzy w stosunku do siebie nie kierują się słusznością, lecz własną korzyścią. Równość zakłada, że osoby mają ten sam status, jak ma to miejsce w przypadku bohaterów tej powieści.

Arystoteles rozumie postępowanie sprawiedliwe jako proporcjonalne, ale według niego, kto posiada wiele, ten daje wiele, lecz również wiele otrzymuje. Jednocześnie w dalszym ciągu swego wywodu zauważa: „niesprawiedliwość jest złamaniem tego, co zostało określone prawem”11.

8 Arystoteles, Etyka nikomachejska, w: Arystoteles, Dzieła wszystkie, t. 5, Warszawa 2000, 1127b.

9 Arystoteles, Etyka wielka, w: Arystoteles, Dzieła wszystkie, t. 5, dz. cyt., 1193b.

10 Arystoteles, Etyka wielka, dz. cyt., 1194a.

11 Arystoteles, Etyka wielka, dz. cyt., 1195a. 
Filozof podkreśla sprawiedliwość jako naczelną wartość porządkującą relacje społeczne. Należy się zastanowić, co to oznacza w praktyce. Dostojewski przedstawia zawikłane losy bohaterów po to, by czytelnik dokonał oceny ich postępowania w sposób sprawiedliwy. Jednakże jeżeli zastosować arystotelesowską definicję sprawiedliwości do osoby Fiodora Karamazowa, wówczas czytelnik staje przed pytaniem, który wykrzyczał na głos Dymitr: „I po cóż żyje taki człowiek!”12 Zwykle literatura nie udziela odpowiedzi wprost, lecz poprzez ukazanie losów bohaterów ułatwia zrozumienie zasadności stosowania istniejącego aksjologicznego porządku opartego na poszanowaniu godności każdego człowieka i uczciwym postępowaniu w relacjach z ludźmi. Pisarz w swojej powieści stawia czytelnika wobec problemu braku uczciwości i sprawiedliwości, a losy bohaterów są aksjologicznymi wskazówkami, mówiącymi o konsekwencjach niesprawiedliwości dla osoby postępującej niesprawiedliwie, ale przede wszystkim dla tych, których ta niesprawiedliwość i nieuczciwość dotyka. Dostojewski, ukazując swych bohaterów, wyraża i opisuje problemy etyczne stojące zarówno przed jednostką, jak i przed całą ludzkością. Opisując świat $\mathrm{w}$ swoich powieściach, nie daje czytelnikowi możliwości dokonania prostych ocen. Wykreowane przez niego postaci są wielowymiarowe, a etyczna ocena ich postępowania jest dla czytelnika niezwykle trudna.

\section{Uczciwość w relacjach między bohaterami powieści Bracia Karamazow}

Zawiłość relacji między bohaterami dzieła i konsekwencje nieprzestrzegania podstawowych zasad etycznych ukazuje twórca, przedstawiając dzieje rodziny Karamazowów. Michał Bachtin uważa, że „głębiny ludzkiej duszy, których przedstawienie uważa Dostojewski za główny cel swego pisarstwa, można odsłonić jedynie w bliższym i intensywnym kontakcie z jego prozą"13. Autor pragnie „znaleźć człowieka w człowieku”14.

\footnotetext{
12 F. Dostojewski, Bracia Karamazow, przeł. A. Wat, oprac. J. Smaga, Wrocław 2013, s. 112.

13 M. Bachtin, Problemy poetyki Dostojewskiego, Warszawa 1970, s. 380-381.

14 M. Bachtin, Problemy..., dz. cyt., s. 92.
} 
Istotną cechą pisarstwa Dostojewskiego jest umiejętność prezentowania dramatu ludzkiej egzystencji, dlatego tytuły powieściowe Zbrodnia i kara, Biesy czy Bracia Karamazow nie służą oznaczeniu problemów i zjawisk jednostkowych, ale poprzez skrót, ujęcie w schemat uosabiają symbolicznie ogólne pojęcia etyczne, które weszły w powszechny obieg, a więc pojęcia krzywdy, ukaranego, czyli odkupionego występku, sprawiedliwości i uczciwości oraz naruszenia potocznego sposobu wartościowania i myślenia o wartościach ${ }^{15}$.

Głównym problemem nurtującym pisarza było pytanie o kryterium ludzkiej moralności. Czym kieruje się człowiek, postępując uczciwie lub nieuczciwie? Na przestrzeni wieków fenomen uczciwości był poddawany analizie i ocenie przez wielu twórców literatury. W swojej ostatniej powieści Dostojewski prezentuje najważniejsze wartości w postaci wielowymiarowych relacji między poszczególnymi bohaterami powieści. Pisarz trafnie diagnozuje brak uczciwości w relacjach pomiędzy poszczególnymi bohaterami jako bezpośrednią przyczynę wielu nieszczęść i problemów, które ich dotykają.

Należy zastanowić się nad fenomenem uczciwości w ujęciu Arystotelesowskim oraz nad sposobem jego prezentacji w powieści Dostojewskiego. W zgodzie z prawdą postępuje tylko jeden spośród trzech braci najmłodszy Aleksy. Jako jedyny zawsze w swoich relacjach z innymi jest szczery i uczciwy. Potrafi, mimo wielu cierpień i krzywd, jakich doznał od ojca, żywić do niego ciepłe uczucia. Fiodor Karamazow wyczuwa w nim uczciwość i szczerość, które powodują, że zdobywa się na uczciwą ocenę własnej osoby, gdy zwraca się do syna: „Przy tobie tylko mam dobre chwile, bo ja przecie jestem zły człowiek” ${ }^{16}$. Brak uczciwości jest przyczyną nieszczerych relacji i prowadzi do rodzinnej tragedii ${ }^{17}$. Alosza uważa, że ojciec zagubił się i nie potrafi dokonywać trafnych wyborów etycznych.

15 Por. H. Brzoza, Dostojewski - myśl a forma, Łódź 1984, s. 134.

16 F. Dostojewski, Bracia..., dz. cyt., s. 239.

17 F. Dostojewski, Bracia..., dz. cyt., s. 56-69. 
Dzięki wyborze drogi życia, którą jest postawa pełna współczucia, empatii i przebaczenia, Alosza może być uczciwy w stosunku do siebie. Umożliwia mu to również uczciwe postępowanie w relacjach z ojcem, ale także w stosunku do obu braci, których wady dostrzega, ale ich nie potępia i nie piętnuje, a zalety podkreśla i podziwia. Alosza jest człowiekiem prawym, bo w swoich relacjach $\mathrm{z}$ innymi kieruje się sprawiedliwością i prawdą, lecz jednocześnie nie potrafi w sposób skuteczny przeciwdziałać rodzinnej tragedii. Przyczyną jego porażki jest nadmierna łagodność, która uniemożliwia mu obiektywną ocenę sytuacji. Alosza widzi ludzi lepszymi, niż są w rzeczywistości, ponieważ oceniając innych, kieruje się przyjaźnią, a nie faktami. Arystoteles uważa, że prawdziwymi przyjaciółmi są ludzie etycznie dzielni ${ }^{18}$. Alosza jest bohaterem etycznie dzielnym w rozumieniu Arystotelesowskim, ale czy za takiego możemy uznać Iwana czy Dymitra? Raczej nie, ponieważ żaden z nich nie postępuje uczciwie, a według Stagiryty męstwo, umiarkowanie i poczucie sprawiedliwości to podstawowe zalety etyczne ${ }^{19}$.

Dostojewski ukazuje relacje zachodzące między braćmi jako skomplikowane i złożone. Często są one oparte na kłamstwie, jak to ma miejsce w przypadku Iwana, który obiecuje Aloszy, że będzie bronił ojca przed gniewem Dymitra, a w rzeczywistości niemal od razu go opuszcza w nadziei, że Dymitr zamorduje ojca. Iwan jest postacią wielowymiarową i trudną do jednoznacznej oceny. Odczuwa cierpienia moralne, które mają wpływ na jego postępowanie względem ojca i braci. Iwan męczy się sam ze sobą, pragnąc odnaleźć cel i sens swojego życia poza moralnością opartą na tradycyjnych wartościach. U Dostojewskiego człowiek cierpi, ponieważ nie znajduje oparcia $\mathrm{w}$ ogólnie przyjętych wartościach, a człowiek pozbawiony wartości nie potrafi odnaleźć swojego miejsca w otaczającej go rzeczywistości. Iwan nie potrafi zdobyć się na uczciwość względem siebie, by przyznać, że ojca uważa za pasożyta, który nie ma prawa do życia, że nienawidzi go i pragnie jego śmierci. Nie jest uczciwy w stosunku do innych, nie umie przyznać,

18 Por. Arystoteles, Etyka nikomachejska, dz. cyt., 1157a.

19 Por. Arystoteles, Etyka nikomachejska, dz. cyt., 1103a. 
że jest zakochany w Katarzynie Iwanownie, rzadko mówi szczerze, zaś w sytuacjach trudnych i niejednoznacznych (kłótnia Dymitra z ojcem lub wizyta u Starca Zosimy) przyjmuje postawę ambiwalentną. Iwan doskonale wie, że Dymitr może zostać obciążony winą za zbrodnię, ale nie ma zamiaru zapobiec nadchodzącym wypadkom. Iwan Karamazow obwinia się za czyn niepopełniony przez siebie bezpośrednio, ani - rozpatrując to w sposób racjonalny - nawet pośrednio, ponieważ jest świadomy, że swoim nieuczciwym postępowaniem względem ojca, Smierdiakowa i Dymitra ponosi odpowiedzialność moralną za zabójstwo rodzica. W sądzie odważnie i uczciwie przyznaje się do swych zbrodniczych myśli wobec ojca i uznaje się za współodpowiedzialnego za zbrodnię, jednak ze względu na zły stan zdrowia nikt nie bierze pod uwage jego zeznań.

Ostatni z braci - Dymitr jest postacią złożoną. Jest człowiekiem prawdomównym i uczciwym - cechy te połączone $\mathrm{z}$ wybuchowością i nieokiełznaną naturą stają się przyczyną tragedii. Jego relacje z ojcem od początku są naznaczone kłamstwem i nienawiścią. Chciwość i zachłanność starego Karamazowa potęguje jeszcze nienawiść Dymitra do ojca, który prowokuje go, poniża i doprowadza do granic wytrzymałości. Dymitr przez osoby postronne postrzegany jest jako człowiek wielkoduszny i uczciwy, ale jednocześnie hulaka, hazardzista i szubrawiec. Tak skrajne cechy doprowadzą go do upadku.

W powieści Bracia Karamazow występuje wiele motywów wskazujących na etyczne, filozoficzne i psychologiczne wyczucie pisarza, zwracającego uwagę czytelnika na wartość uczciwości i sprawiedliwości, których przestrzeganie umożliwia prawidłowe funkcjonowanie jednostki $\mathrm{w}$ relacjach $\mathrm{z}$ innymi ludźmi.

\section{Powieść - tragedia}

Literatura bardzo często odwołuje się do podstawowych wartości etycznych, ukazując ich rolę w życiu człowieka. Celem dzieła literackiego jest zaprezentowanie spektrum ludzkich problemów i przeżyć, przez ujęcie świata przedstawionego w znaczący obraz, który umożliwi jego 
interpretację ${ }^{20}$. W dzieło literackie wpisane są wzory postaw życiowych, jakie człowiek przyjmuje wobec świata, wobec innych oraz wobec życia w ogóle ${ }^{21}$.

Ukształtowanie utworu według kompozycji otwartej, czyli odwołanie się do gatunków literackich o luźnej kompozycji i niekonsekwentnych zasadach, jak np. powieść, sugeruje ukazanie świata jako nieprzewidywalnego, chaotycznego, nieuporządkowanego, świata pełnego sprzeczności, którego nie można całkowicie zrozumieć. Jednocześnie kreacje bohaterów literackich Dostojewskiego i podnoszone przez niego tematy mają znamiona tragedii. Powieść Bracia Karamazow oprócz cech charakterystycznych dla tego gatunku jest jednocześnie przestrzenią tragizmu. Dzieło wyróżnia się zmiennością literackich form podawczych oraz dodatkowymi przesłaniami ideowymi wyrażonymi w formie „wypowiedzi cudzych”, które wzajemnie na siebie wpływają, tworząc powieść polifoniczną sięgającą daleko poza granice gatunku powieściowego ${ }^{22}$. Arystoteles, tworząc definicję tragedii, stwierdza: „Tragedia jest naśladowczym przedstawieniem akcji prowadzonej przez postacie działające, postacie te muszą odznaczać się jakimiś właściwościami myślenia [diánoia] i charakteru [éthos]. Dzięki tym właściwościom oceniamy przecież ich postępowanie" 23 .

Bohaterowie powieści Dostojewskiego, niczym bohaterowie tragedii antycznych, stają wobec wielu problemów, nierzadko nie umiejąc ich rozwiązać. $W$ tragedii oprócz bohatera tragicznego występują również inne postaci, których rola dla spełnienia się losu bohatera tragicznego jest kluczowa. Takim bohaterem w tragedii Antygona Sofoklesa jest Kreon - bez jego uporu i pychy [hybris] nie doszłoby do tragedii, zaś w powieści Dostojewskiego podobną rolę odgrywa Iwan, który pośrednio przyczynia się do zabójstwa ojca, ale również do skazania Dymitra.

20 Por. W. Dilthey, O istocie filozofii i inne pisma, Warszawa 1987, s. 125-128.

21 Por. W. Dilthey, O istocie..., dz. cyt., s. 139-140.

22 Por. M. Bachtin, Problemy poetyki Dostojewskiego, dz. cyt., s. 47-50.

23 Arystoteles, Poetyka, przeł. H. Podbielski, Wrocław 1983, 1450a. 
Kiedy na kartach swej powieści pisarz przedstawia historię nie rodziny, ale jak sam określa „rodzinki” ${ }^{24}$ Karamazowów, robi to, używając retrospekcji. Dostojewski umożliwia odbiorcy zapoznanie się od początku z dziejami „rodzinki” Karamazowów, aby czytelnik odczuwał dylemat moralny, by czuł niedosyt i niepokój oraz „litość i trwogę”. Podobnie czynią autorzy greckich tragedii - odwołują się do mitów, które widzowie tragedii dobrze znają.

Dostojewski zaczyna od przedstawienia ojca trzech bohaterów. Wyłania się obraz człowieka zdemoralizowanego, bezwzględnego, nieuczciwego, chciwego, rozpustnego, pozbawionego jakichkolwiek zasad. Pisarz rysuje grubą kreską postać ojca, który swoim postępowaniem odpowiadał moralnie za śmierć pierwszej żony, a drugą doprowadził do obłędu i w konsekwencji do przedwczesnej śmierci. Czytelnik czuje do niego wstręt i pogardę, zaś informacja, że został on zamordowany przez jednego z synów nie budzi ani zdziwienia, ani oburzenia. Czy Fiodor Karamazow zasłużył na swój los? Wszak popełnił wiele czynów haniebnych, a jego postępowanie względem swoich obu żon i dzieci można nazwać okrutnym i bezwstydnym, co i tak nie odzwierciedla całej podłości tej postaci.

Pisarz stawia czytelnika przed dylematem: czy wobec każdego ojca dzieci mają obowiązki? Czy ojciec, który jest wyzuty z zasad moralnych, który z własnymi dziećmi postępuje nie tylko nieuczciwie, ale wręcz podle, zasługuje na szacunek tych dzieci tylko dlatego, że je spłodził? $\mathrm{Z}$ dylematem mamy do czynienia wówczas, gdy sytuacja wymaga podjęcia dramatycznej decyzji, kiedy to dwa niedające się ze sobą pogodzić działania lub zaniechania mają po swojej stronie rozstrzygające racje $\mathrm{e}^{25}$. Analizując stwierdzenie Arystotelesa, że każdy powinien otrzymać tyle, ile wnosi ${ }^{26}$, można uznać, że Fiodor Karamazow dostał to, na co zasłużył.

Dylemat moralny przeżywa Iwan, który z jednej strony gorąco nienawidzi ojca i pragnie jego śmierci podobnie jak Dymitr, ale z drugiej

24 F. Dostojewski, Bracia..., dz. cyt., s. 24.

25 Por. B. Chyrowicz, O sytuacjach bez wyjścia w etyce, Kraków 2008, s. 50-51.

26 Por. Arystoteles, Etyka wielka, dz. cyt., 1194b. 
strony sam nie chce go zabić. Iwan to postać niejednoznaczna, która w swojej skłonności do okrucieństwa i egoizmie przypomina ojca, ale jednocześnie jest milczący, zamknięty w sobie. Odczuwa wobec ojca bezgraniczną pogardę, ale jednocześnie obawia się, że jest do niego podobny. Uważa, że bycie Karamazowem uniemożliwia mu bycie człowiekiem wolnym od nienawiści, uczciwym i prawdomównym wobec innych, ale również, a może przede wszystkim, wobec siebie. Iwan jest człowiekiem wykształconym, prezentującym nowoczesne poglądy, wielbicielem Rozumu, który uznaje za wartość najwyższą. Wygłaszane przez niego idee sprawiły, że stał się mimowolnym sprawcą zbrodni ojcobójstwa, do której doprowadził „wbrew swej woli”, podobnie jak Kreon, który swym postępowaniem doprowadził do śmierci nie tylko Antygony, lecz także swego syna Hajmona i żony Eurydyki ${ }^{27}$. Gdyby Iwan potrafił zdobyć się na uczciwość względem Dymitra, nie doszłoby do tragedii.

Niestety to nie jedyny dylemat moralny, jaki przeżywają bohaterowie powieści - ten najważniejszy, który prześladuje również czytelnika, wypowiada Alosza: „Czy istotnie każdy człowiek ma prawo zapytać, patrząc na innych ludzi: który z nich godzien jest żyć, a który niegodzien?" 28 . W trakcie lektury czytelnik wielokrotnie staje przed tym dylematem, a Dostojewski, dokonując rozprawy ze swoimi bohaterami racjonalistami, zdaje się udzielać odpowiedzi negatywnej. Pisarz uważa, że człowiek bez zasad jest istotą wyobcowaną, pozbawioną oparcia i zdaną na rozpaczliwe poszukiwania ,idoli”, a takim człowiekiem mieni się Iwan Karamazow oraz jego literacki brat - Rodion Raskolnikow ${ }^{29}$. Obydwaj uważają się za buntowników, ateistów, którzy mogą decydować o tym, kto ma prawo żyć. Rodion sam dokonuje morderstwa lichwiarki, uzasadniając je swoją wyższością moralną i intelektualną, zaś Iwan nie dokonuje ojcobójstwa w sposób bezpośredni, lecz pośredni ${ }^{30}$. Okrzyk

27 Sofokles, Antygona, przeł. K. Morawski, Wrocław 1995.

28 F. Dostojewski, Bracia..., dz. cyt., s. 217.

29 Por. B. Urbankowski, Dostojewski: dramat humanizmów, Warszawa 1994, s. 232.

30 Por. H. Brzoza, Dostojewski. Między mitem, tragedia i apokalipsą, Toruń 1995, s. 314. 
Iwana Karamazowa: „Jeżeli Bóg umarł, to wszystko jest dozwolone”31 oznacza zakwestionowanie wszystkiego, nie tylko wartości etycznych.

Ostatni i najmłodszy z braci - Alosza Karamazow - to całkowite przeciwieństwo Dymitra i Iwana. To człowiek spokojny, cichy i skromny, ale jednocześnie świadomy swych słabości. Jest lubiany i szanowany. Obydwaj bracia cenią sobie jego zdanie, pomimo jego młodego wieku Aleksy ma zaledwie dwadzieścia lat ${ }^{32}$. Jako jedyny $\mathrm{z}$ braci wybaczył ojcu szczerze, potrafi nawet zdobyć się na miłość do niego, i kocha go tak, jak rodzic kocha niesforne i nieposłuszne dziecko. W miłości do ojca jest wiele pobłażania dla jego słabości. Stary Karamazow wie o tym, że Alosza, kochając go, nie jest ani naiwny i głupi, ani nieuczciwy - wręcz przeciwnie - jest ponad to, ponieważ dzięki wybaczeniu dostępuje katharsis. Alosza uważa, że ojciec pogubił się i nie potrafi dokonywać trafnych wyborów etycznych. Żal mu ojca, i właśnie uczucie żalu stanowi swoiste katharsis dla samego Aloszy, ponieważ uwalnia go od uczucia gniewu i nienawiści wobec rodzica, który go skrzywdził.

Postać najmłodszego z braci jest drogowskazem dla czytelnika - jedynie człowiek, który potrafi przebaczyć drugiemu wyrządzoną krzywdę, może uwolnić się od negatywnych emocji, działających na niego destrukcyjnie. Dymitr i Iwan nie potrafią wyzbyć się nienawiści i pogardy wobec ojca - te uczucia prowadzą ich do zguby moralnej, ale również do samounicestwienia. Splątane i tragiczne losy bohaterów wywołują w odbiorcy dzieła uczucia podobne do tych, które odczuwali widzowie tragedii, ponieważ czytelnik rozumie, że losy bohaterów powieści mogą mieć tragiczny finał.

Powieści Dostojewskiego zawierają w sobie elementy tragiczne, ponieważ ukazują człowieka, w którym mieści się pragnienie tworzenia wyraźnie uporządkowanego świata moralnego oraz rzeczywistości pozwalającej bezproblemowo odróżnić dobro od zła. Człowiek w świecie Dostojewskiego jest targany sprzecznymi uczuciami, staje przed

31 F. Dostojewski, Bracia..., dz. cyt., s. 347.

32 F. Dostojewski, Bracia..., dz. cyt., s. 25. 
trudnymi wyborami dobra albo zła, mając świadomość, że w swym wyborze jest osamotniony - na tym polega jego tragizm.

\section{Dymitr - bohater tragiczny}

Arystoteles w rozdziale XIII Poetyki charakteryzuje bohatera tragedii i zauważa: „nie należy pokazywać ani ludzi nieposzlakowanych popadających ze szczęścia w nieszczęście, gdyż to nie wzbudza litości ni trwogi, a tylko oburzenie, ani też zmiany losu ludzi niegodziwych $\mathrm{z}$ nieszczęścia $\mathrm{w}$ szczęście, bo nic nie jest bardziej obce duchowi tragedii niż taka właśnie struktura; [...] Pozostaje zatem wybór kogoś pośredniego między nimi. Takim bohaterem jest więc człowiek, który nie wyróżnia się osobliwie ani dzielnością i sprawiedliwością, ani też nie popada w nieszczęście przez swą podłość i nikczemność, lecz ze względu na jakieś zbłądzenie"33. Postacią posiadającą cechy konieczne, by być bohaterem tragicznym, jest według Arystotelesa Edyp - bohater jednej z tragedii Sofoklesa, który z jednej strony posiada wybitne przymioty etyczne (heroiczne męstwo i dążenie do prawdy), ale ma niewątpliwe wiele wad, np. jest porywczy, nieufny i przekonany o słuszności swoich racji ${ }^{34}$. Galewicz zwraca uwagę na użyty przez Arystotelesa termin „zbłądzenie” [hamartia], który oznacza w szerokim rozumieniu błąd wynikający z nikczemności, ponieważ człowiek zły lub występny w pewien sposób błądzi, gdyż nie zdaje sobie sprawy z tego, co należy czynić, a czego zaniechać ${ }^{35}$. W przytoczonym fragmencie, pisząc o „zbłądzeniu”, Arystoteles ma na myśli sytuację, w której szkoda wywołana przez czyn była nieprzewidywalna nie tylko przez sprawcę czynu, lecz także przez każdą inną osobę, która znalazłaby się w jego położeniu ${ }^{36}$. Należy zastanowić się, jakie cechy zostały wskazane

33 Arystoteles, Poetyka, dz. cyt., 1453a.

34 Por. W. Galewicz, Z Arystotelesem przez greckie tragedie, Kraków 2003, s. 159.

35 Por. W. Galewicz, Z Arystotelesem..., dz. cyt., s. 160.

36 Por. W. Galewicz, Z Arystotelesem..., dz. cyt., s. 161. 
przez Arystotelesa jako konieczne, by daną postać uznać za godną bycia bohaterem tragedii.

Filozof mówi, że nie może to być postać ani nieposzlakowana, ani niegodziwa. Czy Dymitr spełnia te wymogi? Wydaje się, że tak. W oczach swoich bliskich jest uznawany za" [...] charakter niepohamowany i dający się unosić namiętnościom, ale za to uczciwy, dumny i wspaniałomyślny, skory nawet do poświęceń" ${ }^{37}$ - te słowa na temat najstarszego brata wypowiada Alosza. Dymitr ma „szeroką, karamazowską naturę, która mieści w sobie wszelkie krańcowości i jednocześnie jest zdolna kontemplować obie otchłanie: otchłań wzniosłych ideałów, otchłań nad nami i otchłań pod nami, otchłań najniższego i cuchnącego upadku"38. Jest postrzegany jako osoba pełna sprzeczności, nieprzewidywalna i wzbudzająca wiele kontrowersji. Czy Dymitr to człowiek pozbawiony zasad moralnych? Na pewno jest nieodrodnym synem swego ojca w swoim niepohamowaniu emocji, uleganiu rozpuście, skłonności do hazardu, ryzyka i kobiet, ale jest również człowiekiem wielkodusznym i hojnym. Często podkreślana jest jego uczciwość i prawdomówność. Na sytuację bohatera miały wpływ zaburzone relacje z ojcem, od samego początku przesiąknięte nieuczciwością, nienawiścią i pogardą.

Charakter Dymitra jest, z perspektywy opisu Arystotelesa, idealny dla bohatera tragedii. Posiada on wiele zalet, ale jednocześnie ma liczne wady. W dalszym ciągu swych rozważań Arystoteles pisze o „popadnięciu w nieszczęście" jako koniecznym wyznaczniku tragiczności losu bohatera. Dymitr Karamazow prowadzi życie lekkomyślne, nierzadko hulaszcze i rozwiązłe, ale popada $\mathrm{w}$ wielkie nieszczęście nie $\mathrm{z}$ powodu swych czynów rozwiązłych czy lekkomyślnych, lecz z powodu fatalnego splotu niesprzyjających okoliczności. Jest niewinny zarzucanego mu czynu, ale nie jest człowiekiem szanowanym i wzbudzającym sympatię, wręcz przeciwnie, jest znany ze swej gwałtowności, skłonności do kłótni, a poza tym dla nikogo nie jest tajemnicą, że szczerze nienawidził ojca i wielokrotnie groził, że go zabije. Dymitr zdaje sobie sprawę

37 F. Dostojewski, Bracia..., dz. cyt., s. 974.

38 F. Dostojewski, Bracia..., dz. cyt., s. 1008. 
z własnych wad, potrafi zdobyć się na szczerość i ocenić swój charakter, o czym świadczą jego słowa na sali sądowej: „Przyznaję, że jestem winien pijaństwa i rozpusty [...] lenistwa i skandali. [...] Ale śmierci starca, mego wroga i ojca - nie jestem winien! Ale grabieży - nie, nie, nie jestem winien i nie mogę być winien: Dymitr Karamazow jest łajdakiem, ale nie złodziejem!" 39 . Postać najstarszego z braci wzbudza u czytelnika wiele skrajnych emocji, ale o to właśnie chodzi Dostojewskiemu, który potrafi wydobyć na powierzchnię wiele dwuznacznych sytuacji, utrudniając odbiorcy ocenę bohaterów i zdarzeń ${ }^{40}$. Los Dymitra zostaje przesądzony dlatego, że jego wcześniejsze czyny zadecydowały o wydaniu nań wyroku skazującego za zbrodnię, której nie popełnił.

Bohater tragedii popada w nieszczęście w wyniku „zbłądzenia” [hamartia] - stwierdza Arystoteles w swoim wywodzie o tragedii. W jaki sposób zbłądził Dymitr? Zbłądzeniem Dymitra są jego emocje, którym łatwo ulega i daje się im zaślepić. Arystoteles wyraźnie podkreśla, że ten, kto ulega żądzom, którym większość ludzi umie się przeciwstawić i je powściągnąć, zachowuje się w sposób niewybaczalny. W swoich rozważaniach na temat wad etycznych zaleca unikanie nikczemności, nieopanowania i bestialstwa ${ }^{41}$. Brak opanowania dotyczy, zdaniem Arystotelesa, szczególnie silnych namiętności, takich jak gniew, chciwość czy uleganie pokusom i rozpuście. Zastanawiając się nad postępowaniem Dymitra, należy uznać, że nie jest on ani nikczemny, ani bestialski, natomiast jest nieopanowany, a jego uleganie namiętnościom można uznać za „zbłądzenie”. „Zbłądzeniem” Dymitra jest nienawiść do ojca, która go niszczy i deprawuje. Jego błędem jest to, że nie potrafi, ale również nie chce, się od niej uwolnić. Nienawiść do ojca zaślepia go, powoduje, że przestaje racjonalnie myśleć, postępuje lekkomyślnie i gwałtownie, a konsekwencje ulegania przez niego namiętnościom przyniosą mu zgubę.

Arystoteles wiele uwagi poświęca nieopanowaniu gniewu, który uważa za mniej szkodliwy niż uleganie żądzom zmysłowym, ponieważ

39 F. Dostojewski, Bracia..., dz. cyt., s. 954.

40 Por. K. Burke, Filozofia formy literackiej, Gdańsk 2014, s. 50-51.

${ }^{41}$ Por. Arystoteles, Etyka nikomachejska, dz. cyt., 1145a-1145b. 
gniew „zdaje się słyszeć nakazy rozumu, lecz nie dosłyszeć ich dobrze”42, zaś żądza tego nie czyni. Dymitr zna siebie, dlatego unika bezpośredniej konfrontacji z ojcem, bojąc się, że nie zdoła opanować swojej nienawiści i gniewu. Alosza, znając swojego brata, mówi: „Ja zawsze byłem przekonany, że jakieś szlachetniejsze uczucie zbawi go w takiej fatalnej chwili, jak go istotnie zbawiło, bo to nie on zabił ojca"43. Dymitr potrafił zapanować nad swym gniewem i, mimo że był tego bliski, nie zabił swego ojca, chociaż nienawidził go z całego serca. Dymitr, podobnie jak Edyp, przyjmuje swój los i godzi się odbyć dwudziestoletnią katorgę za czyn niepopełniony, ponieważ uważa, że inne jego postępki domagają się kary, a katorga pomoże mu się odrodzić i odkupić swoje winy. Edyp ponosi karę za zbrodnie popełnione nieświadomie, zaś Dymitr ponosi karę za gotowość do popełnienia zbrodni. Godzi się dobrowolnie na odbycie kary za ojcobójstwo, ponieważ wie, że był o krok od dokonania tej zbrodni, rozumie również, że swoją zaciekłością przyczynił się do jej popełnienia. Pogodzenie się z losem jest elementem koniecznym do tego, by uznać Dymitra za bohatera tragicznego, którego popadnięcie w nieszczęście nie jest wynikiem podłości i nikczemności - gdyby naprawdę zabił swego ojca, to według obowiązujących norm moralnych zasłużyłby na karę, można by było rozpatrywać jej wymiar, brać pod uwagę okoliczności łagodzące (postępowanie ojca), ale ojcobójstwo jest bez względu na okoliczności uważane za jedną z najcięższych zbrodni. W przypadku Dymitra zbrodnia nie została popełniona, lecz wstrząs moralny skłania go do przyjęcia kary, która stanowi dla niego swoiste oczyszczenie [katharsis] i szansę na nowe życie. Dla bohatera tragicznego, którego winą jest „zbłądzenie”, kara jest szansą na odnalezienie właściwej drogi.

42 Arystoteles, Etyka nikomachejska, dz. cyt., 1149a.

43 F. Dostojewski, Bracia..., dz. cyt., s. 974. 


\section{Podsumowanie}

Wielka literatura może mieć wpływ na kształtowanie się postaw moralnych czytelnika. Często z dzieł literackich dowiadujemy się o rzeczywistych cechach natury ludzkiej, co odgrywa kluczową rolę w kształtowaniu się naszych opinii i postaw etycznych. Literatura spełnia wobec etyki funkcję heurystyczną, ponieważ dostarcza jej przykładów, które dzięki pochodzeniu z życia codziennego są bliższe i bardziej zrozumiałe doświadczeniu odbiorcy niż tezy zawarte $\mathrm{w}$ pismach filozoficznych. Istotną cechą literatury jest umiejętność wzbudzania emocji i nastrojów oraz generowania czegoś, co jest podobne do zmysłowych doświadczeń ${ }^{44}$.

Celem artykułu jest ukazanie analizy etycznej dzieł literackich jako sposobu interpretowania i odbioru samego dzieła przez pryzmat ukazanych w nim wartości. Literatura uczy samodzielnego myślenia i krytycznego spojrzenia na otaczający świat, ale uczy nie wprost, lecz poprzez opisane przykłady, świat przedstawiony, kreacje bohaterów, ich zachowania, sposób myślenia i postępowania, ale również poprzez ich losy, które są konsekwencją ich działań.

W artykule została zastosowana metoda analizy etycznej w celu przedstawienia znaczenia fenomenu uczciwości dla relacji społecznych na przykładzie powieści Fiodora Dostojewskiego Bracia Karamazow. Aby dokonać oceny etycznej postaci i działań bohaterów powieści, posłużyłam się Etykq nikomachejska oraz Etykq wielkq Arystotelesa. W pracy zostały ukazane cechy powieści Dostojewskiego, które pozwalają na interpretację dzieła jako powieści - tragedii, umożliwia to ranga poruszanych przez pisarza największych problemów etycznych, które dotykają człowieka. W Poetyce Arystoteles dokonuje oceny dzieła literackiego z perspektywy jego walorów poznawczych, estetycznych i etycznych. W ostatniej części artykułu została przedstawiona charakterystyka jednego z tytułowych bohaterów powieści, Dymitra z uwzględnieniem cech umożliwiających uznanie go za bohatera tragedii, którego czyny

44 Zob. A. Głąb, Literatura..., dz. cyt., s. 13. 
nie wynikają z nikczemności i podłości, ale z powodu „zbłądzenia”. Pisanie o uczciwości w oparciu o wybitne dzieło Dostojewskiego nie wyczerpuje tematu, ponieważ prawidłowa relacja zależy od równości uczestników i jest możliwa, jak pisze Arystoteles, tylko przy jej zachowaniu. Relacje społeczne, by spełniać postulat uczciwości, powinny być budowane na fundamencie równości. Dostojewski ukazuje świat, w którym uczciwość i inne wartości etyczne wymagają od uczestników relacji nieustannego zaangażowania w ich budowanie. Wielka literatura odwołuje się do obiektywnie istniejącego porządku moralnego, a korzystanie $\mathrm{z}$ doświadczeń innych ułatwia podejmowanie indywidualnych decyzji w sytuacjach konieczności dokonania wyboru. Literatura ułatwia zastosowanie istniejących norm etycznych o charakterze ogólnym do indywidualnych sytuacji przeżywanych w życiu codziennym.

\section{Bibliografia}

Arystoteles, Etyka nikomachejska, w: Arystoteles, Dzieła wszystkie, t. 5, przeł. D. Gromska, Warszawa 2000, s. 77-300.

Arystoteles, Etyka wielka, w: Arystoteles, Dzieła wszystkie, t. 5, przeł. W. Wróblewski,

Warszawa 2000, s. 301-383.

Arystoteles, Poetyka, przeł. H. Podbielski, Wrocław 1983.

Bachtin M., Problemy poetyki Dostojewskiego, Warszawa 1970.

Brzoza H., Dostojewski - myśl a forma, Łódź 1984.

Brzoza H., Dostojewski. Między mitem, tragedia i apokalipsą, Toruń 1995.

Burke K., Filozofia formy literackiej, przeł. E. Rajewska, Gdańsk 2014.

Chyrowicz B., O sytuacjach bez wyjścia w etyce, Kraków 2008.

Dilthey W., O istocie filozofii i inne pisma, tłum. i wstęp E. Paczkowska-Łagowska, Warszawa 1987.

Dostojewski F., Bracia Karamazow, przeł. A. Wat, oprac. J. Smaga, Wrocław 2013.

Galewicz W., Z Arystotelesem przez greckie tragedie, Kraków 2003.

Głąb A., Literatura a poznanie moralne, Lublin 2016.

Herbut J., Elementy metodologii filozofii, Lublin 2004.

Leksykon filozofii klasycznej, red. nauk. J. Herbut, Lublin 1997. 
Podrez E., Rola wyobraźni w kształtowaniu świadomości moralnej, w: Wyobraźnia jako jaźn twórcza. Studia z etyki, literatury i sztuki, red. nauk. E. Podrez, A. Czyż, Warszawa 2002. Sofokles, Antygona, przeł. K. Morawski, Wrocław 1995.

Stanisz M., Pytania o światopogląd gatunków literackich, w: Filozofia w literaturze. Literatura $w$ filozofii, red. nauk. A. Iskra-Paczkowska, S. Gałkowski, M. Stanisz, Rzeszów 2013.

Urbankowski B., Dostojewski: dramat humanizmów, Warszawa 1994.

\section{Abstrakt}

\section{Analiza etyczna fenomenu uczciwości na podstawie powieści Fiodora Dostojewskiego Bracia Karamazow}

$\mathrm{W}$ artykule została zastosowana metoda analizy etycznej w celu przedstawienia znaczenia fenomenu uczciwości na przykładzie powieści Fiodora Dostojewskiego Bracia Karamazow. Etyka nikomachejska oraz Etyka wielka Arystotelesa zostały wykorzystane do dokonania oceny etycznej bohaterów powieści i ich działań. Ranga poruszanych przez pisarza problemów umożliwia interpretację dzieła jako powieści - tragedii. W ostatniej części artykułu została przedstawiona charakterystyka jednego z tytułowych bohaterów powieści, Dymitra, $\mathrm{z}$ uwzględnieniem cech umożliwiających uznanie go za bohatera tragedii, którego czyny nie wynikają z nikczemności i podłości, ale z powodu „zbłądzenia”. Celem artykułu jest ukazanie analizy etycznej dzieł literackich jako sposobu interpretowania i odbioru samego dzieła przez pryzmat ukazanych w nim wartości.

\section{Słowa kluczowe}

uczciwość, Fiodor Dostojewski, Arystoteles, etyka, literatura 


\section{Abstract \\ The ethical analysis of the phenomenon of honesty in the Fyodor Dostoyevsky novel The Brothers Karamazov'}

This paper is written by using ethical analysis method to depict the significance of phenomenon of honesty by the example of The Brothers Karamazov by Fyodor Dostoyevsky. For this purpose The Nicomachean Ethics and The Great Ethics of Aristotle is used to accomplish an assessment of characters and their behavior. The significance of raising problems in the novel enable interpretation of the composition not only as a novel but also as a tragedy. In the last part of the article characteristic of one of main characters, Dymitry is introduced. His features allow to classify him as a figure of the tragedy, whose actions do not result from dishonorableness or shabbiness but from hamartia. The aim of the article is to show ethical analysis method of literary works as a method of interpretation and reception of a novel by showing values hidden in the text.

\section{Keywords}

honesty, Fyodor Dostoyevsky, Aristotle, ethics, literature 